\title{
RULEMAKING INACTION AND THE FAILURE OF ADMINISTRATIVE LAW
}

\author{
SIDNEY A. SHAPIRO $\dagger$
}

\begin{abstract}
The Trump administration may be the first presidency to go four years without promulgating new significant regulations to protect people and the environment. Although administrative law protects regulatory beneficiaries when agencies revoke or modify previous rules, those protections evaporate when an agency rejects a rulemaking petition, fails to answer a petition for years, or fails to work on pending regulatory protections. In effect, the courts have outsourced agency accountability for rulemaking inaction to political oversight, but as a defense of the interests of regulatory beneficiaries, political accountability is the "Maginot Line" of oversight. Despite the difficulty of judging an agency's claim that it has higher priorities or that it needs more time to make a decision, judges should require more detailed explanations. Although less trusting judicial review is not without its problems, the current approach of abject deference to agency inaction ignores Congress' commitment to protect people and the environment as specified in an agency's mandate.
\end{abstract}

\section{TABLE OF CONTENTS}

Introduction 1806

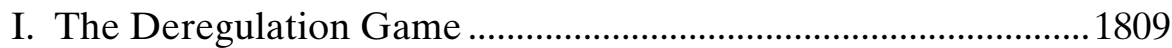

II. The Administrative Law of Deregulation .....................................1812

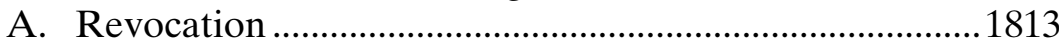

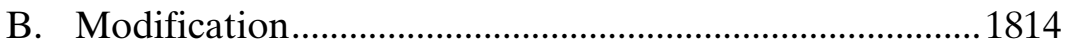

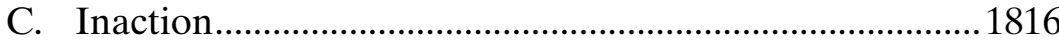

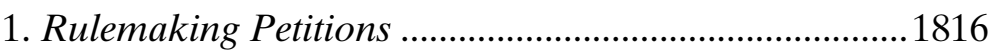

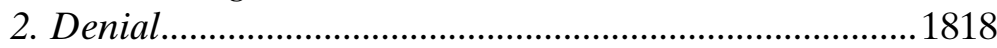

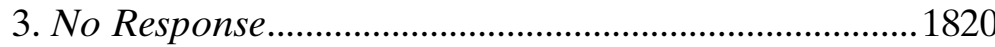

Copyright (C) 2019 Sidney A. Shapiro.

$\dagger$ Frank U. Fletcher Chair of Administrative Law, Wake Forest University School of Law. I am appreciative of the comments and suggestions regarding the Article from the other contributors to this Symposium, Professor Chris Schroeder who commented on the article, and from the other Duke faculty members and students attending the Symposium. As well, I benefited from suggestions made by Professor Richard Murphy. 
4. A Slow Walk 1822

III. Enhanced Accountability ............................................................1823

A. Legal Civics ..................................................................... 1824

B. "The Unbearable Lightness" of Political Accountability

C. Less Passive Judicial Review

IV. Conclusion 1841

\section{INTRODUCTION}

Presidents can pursue deregulation using three strategies: the revocation of rules, the modification of them, or rulemaking inaction. Inaction involves refusing to start any new rules to protect the public or the environment or to delay regulatory rules already started to the point of a crawl. While these steps do remove or modify existing rules, they are still deregulatory. Inaction, despite the name, is deregulatory because, as the Article will develop, Congress creates regulatory agencies with the expectation that they will use their delegated authority to protect people and the environment in the manner that legislation indicates. When an administration engages in rulemaking inaction, it fails this expectation, making its action deregulatory. Moreover, the deregulatory impact is more than four (or eight) years when you consider it will take a proregulatory administration years to adopt a regulation after it takes office. Fans of the television show Parks and Recreation will recognize this as the "Ron Swanson" strategy. ${ }^{1}$

President Trump is unique among presidents in channeling Ron Swanson. Other administrations have employed rulemaking inaction as a deregulatory strategy. In the Reagan administration, for example, the Occupational Safety and Health Administration ("OSHA") issued no new health standards for five years. ${ }^{2}$ It is probably not coincidental that the two administrators of OSHA during that period were both extremely hostile to the agency's mission. ${ }^{3}$ But the Trump

1. Swanson, a fictional character from the situational comedy television series Parks and Recreation, is the director of the parks and recreation department of a fictional city in Indiana who, as a strong libertarian, supports the elimination of his department since public parks should not even exist and, in the meantime, strategizes how to do nothing to advance the mandate of his department. See WIKIPEDIA, Ron Swanson, https://en.wikipedia.org/wiki/Ron_Swanson [https://perma.cc/ZXM8-WDRV].

2. THOMAS O. MCGARITY \& SIDNEY A. SHAPIRO, WORKERS AT RISK: THE FAILED Promise of THE OCCUPATIONAL SAFETY AND HEALTH AdMinistration 61-63 (1993).

3. See id. 
administration is the first to employ this tactic on a government-wide basis. President Trump's executive order requiring agencies to eliminate two rules for each new regulatory rule they promulgate has stopped the entire government from adopting regulatory rules. ${ }^{4}$ In 2017, the regulatory agenda indicated that agencies took sixty-seven deregulatory actions and only three regulatory actions. ${ }^{5}$ There is no doubt that agencies in the Trump administration can defend their lack of interest in new protective regulation as simply a matter of priority setting - they are too busy deregulating - but the question remains whether the courts should accept this claim as existing administrative law appears to require them to do.

Among the three deregulatory strategies, administrative law provides the weakest check - an almost nonexistent check in fact-on rulemaking inaction as a strategy of deregulation as compared to revocation and modification. Although scholars have noted the impact of rulemaking inaction on protection of the public and the environment, they have been reluctant to support changing the existing approach to judicial review because of the judiciary's difficulty in judging agency priorities. ${ }^{6}$

This Article challenges the current judicial calculus that elevates the significance of agency priority setting while giving little or no weight to the significance of legislative commitments to protect people and the environment. My starting point is the recognition that rulemaking inaction can, and sometimes is, a deregulation game, exploiting administrative law for ideological motivations. If administrative law is to ensure that administrative decisions are a matter of law, and not simply ideology, courts must raise their

4. See Exec. Order No. 13771, 82 Fed. Reg. 9339 (2017).

5. Clyde Wayne Crews, Jr., Trump's 2018 Regulatory Reform Agenda By the Numbers, FORBES (May 10, 2018, 1:21 PM), https://www.forbes.com/sites/waynecrews/2018/05/10/trumps2018-regulatory-reform-agenda-by-the-numbers/\#53a5fc97cd29 [https://perma.cc/4QSX-ASL3]. The Executive Order only applies to significant regulations, but some significant regulations are exempt from the order. See Cheryl Bolen, Trump's 2-for-1 Regulatory Policy Yields Minimal Results, BloOMBERG L. (Sept. 29, 2017), https://www.bna.com/trumps-2for1-regulatoryn73014470324/ [https://perma.cc/GA7T-X6WL].

6. See, e.g., Michael D. Sant'Ambrogio, Agency Delays: How a Principal-Agent Approach Can Inform Judicial and Executive Branch Review of Agency Foot-Dragging, 79 GEO. WASH. L. REV. 1381, 1427-31 (2011); Cass R. Sunstein \& Adrian Vermeule, The Law of "Not Now": When Agencies Defer Decisions, 103 GEO. L.J. 157, 161, 172-76 (2014) (discussing the Supreme Court's recognition of agency discretion in priority setting in Heckler v. Chaney, 470 U.S. 821 (1985)); see generally, e.g., Eric Biber, Two Sides of the Same Coin: Judicial Review of Administrative Agency Action and Inaction, 26 VA. ENVTL. L.J. 461 (2008) (arguing that courts should defer to agencies in resource allocation among competing priorities). 
expectations about what constitutes a satisfactory justification for putting protective regulations at the back of a queue. A lack of curiosity is a failure of administrative law, not an implementation of it.

My analysis begins with the deregulation game. In analyzing the strategic choices available to agencies from a positive political perspective, the choice of rulemaking inaction, despite the opposition of regulatory beneficiaries, is the strategy the courts are most likely to accept. Moreover, if Congress is aligned with the president, the strategy is likely to be supported by both it and regulated entities.

Administrative law also aids and abets this strategic choice. Because the revocation of rules must overcome the rulemaking record established by the adopting agency, the revoking agency must persuade a court that there is no need for a rule-some rule-which is likely to be difficult. Rather, an agency is better off modifying a rule because judges recognize that an agency has more than one nonarbitrary policy option. Nonetheless, judicial review still has some bite because the modifying agency must choose among those reasonable options. The courts are most likely to accept rulemaking inaction because judges use abject deference to review such actions, and because petitioners do not have a record on which they contest agency claims about rulemaking priorities.

The last Part contends the current judicial approach to rulemaking inaction fails to fulfill the function of administrative law as "legal civics"-requiring an agency to offer reasons that justify its action as implementing its statutory mandate. Specifically, judicial review of agency action, as currently practiced, is so deferential that it effectively ignores Congress' commitment to protect people and the environment as specified in an agency's mandate. That mandate is not neutral between action and inaction. It is not ambivalent between regulation and the lack of regulation. Instead, the role of the courts is therefore to establish both a ceiling and a floor that cabins the policy space in which an agency can operate. Just as an agency cannot exceed the legal authority delegated by Congress, it also cannot avoid its statutory obligation to protect the public.

The courts today only enforce the ceiling. It is time-past time, really - that judges enforce the floor as well. If administrative law is to require that agencies operate in a legal manner-that is, within the bounds of their statutory mandate-courts must stop giving agencies carte blanche concerning rulemaking inaction. Otherwise, administrative law will continue to fail to recognize rulemaking inaction as an illegitimate and undemocratic act. 


\section{THE DeREgulation GAME}

In analyzing the strategic choices available to political actors, analysts have employed a game theoretic model that identifies likely outcomes based on structural factors that shape political behavior, such as constitutional or legal rules. ${ }^{7}$ When you model an administration's options to engage in deregulation as a set of strategic choices, it illustrates that rulemaking inaction is likely to be the most successful of the three deregulatory strategies. Although this choice does not eliminate regulation, it nevertheless is deregulatory because it can postpone any new protective regulations for years, even if a president is not elected for a second term. It has this impact because under existing structural factors, particularly agency resources and judicial expectations, it takes anywhere from four to eight years or more to promulgate a significant rule in any administration that follows the administration committed to inaction. ${ }^{8}$

A president with a deregulation agenda can direct agencies to revoke rules, modify them, or choose not to promulgate new regulatory rules. The following diagrams model the strategic preferences of

7. See generally, e.g., Douglas G. BAIRd, Robert H. GerTner \& RANDAL C. Picker, GAME THEORY AND THE LAW (1994) (using game theory to illustrate the different kinds of legal problems); William N. Eskridge, Jr. \& John Ferejohn, The Article I, Section 7 Game, 80 GEO. L.J. 523 (1992) (applying game theory to analyzing Article I, Section 7 of the Constitution); Jerry L. Mashaw, Improving the Environment of Agency Rulemaking: An Essay on Management, Games, and Accountability, 57 LAW. \& CONTEMP. PROBS. 185 (1994) (applying game theory to analyzing OSHA and EPA rulemaking); Eric R. Claeys, Note, The Article III, Section 2 Games: A GameTheoretic Account of Standing and Other Justiciability Doctrines, 67 S. CAL. L. REV. 1321 (1994) (applying game theory to analyzing justiciability doctrines).

8. For an explanation of why a rule takes a minimum of between 47 and 95 months to promulgate, see Regulatory Accountability Act of 2011: Hearing on H.R. 3010 Before the Judiciary Comm., 112th Cong. 6 (2011) (testimony of Sidney A. Shapiro, University Distinguished Chair in Law, Wake Forest School of Law), http://www.progressivereform.org/articles/Shaprio_RAA_ Tesimony_102511.pdf [https://perma.cc/7XUZ-AGUM]. For a general discussion of the ossification of rulemaking, see JERRY L. MASHAW \& DAVID L. HARFST, THE STRUGGLE FOR AUTO SAFETY 9-25 (1990) (discussing abandonment of rulemaking by the NHTSA); Frank B. Cross, Pragmatic Pathologies of Judicial Review of Administrative Rulemaking, 78 N.C. L. REV. 1013, 1020-27 (2000); Thomas O. McGarity, Some Thoughts on “Deossifying” the Rulemaking Process, 41 DUKE L.J. 1385, 1387-1436 (1992). Some scholars have disputed that the rulemaking delay is a serious problem. See, e.g., Jason Webb Yackee \& Susan Webb Yackee, Testing the Ossification Thesis: An Empirical Examination of Federal Regulatory Volume and Speed, 1950 1990, 80 GEO. WASH. L. REV. 1414, 1421 (2012). But this empirical work fails to account for the fact that controversial, significant rules take years, while other noncontroversial, minor rules take much less time. See Richard J. Pierce, Jr., Rulemaking Ossification Is Real: A Response to Testing the Ossification Thesis, 80 GeO. WASH. L. REV. 1493, 1497-98 (2012); Sidney A. Shapiro \& Richard W. Murphy, Arbitrariness Review Made Reasonable: Structural and Conceptual Reform of the "Hard Look," 92 Notre DAME L. REV. 331, 354 (2016). 
regulatory beneficiaries (B), Congress $(C)$, regulated entities (E), and the president $(\mathrm{P})$. The likelihood that judges $(\mathrm{J})$ will affirm the president's preferred policy is found above the line in the diagrams. The distance between the actors, as pictured, is inexact, and the illustrations are meant to indicate a comparative or relative ordering. In Figure 1, the president $(\mathrm{P})$ and regulated entities $(\mathrm{E})$ are pictured as preferring revocation as a deregulatory strategy. Congress (C) is likewise supportive, but regulatory beneficiaries (B) have a strong preference against revocation. The courts $(\mathrm{J})$ are depicted in Figure 1 as being resistant to the revocation of rules, although not as much so as regulatory beneficiaries (B).

In Figure 1, there is a significant gap between the president's policy preference to revoke existing regulations and the likelihood the courts will affirm a revocation. To be sure, the outcome of judicial review can vary depending on the ideological preferences of the judge, ${ }^{9}$ but a judge is less likely to act strategically when an administration has clearly or obviously violated legal doctrines or its statutory mandate. ${ }^{10}$ The judge's behavior is therefore bounded because at some point an agency's deregulatory decisions are likely to be clear violations of existing case law as explained in Part II.A.

Figure 1: Revoke

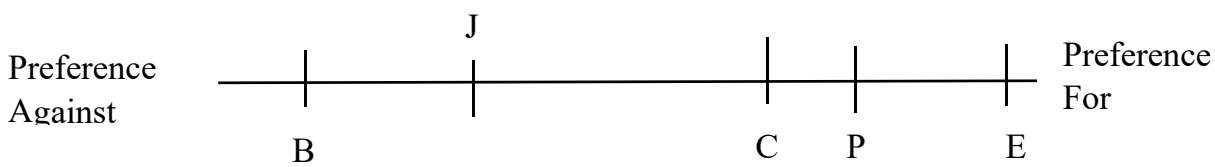

Figure 1 assumes the administration and regulated entities have similar preferences for revoking a rule, but those conditions will not always hold. For example, regulated entities may not have a strong preference for the revocation of rules because, having already come into compliance with rule, a significant portion of the cost of compliance is a sunk cost for them. Then again, a president might have a weaker preference for the revocation of rules than regulated entities

9. See Thomas J. Miles \& Cass R. Sunstein, Do Judges Make Regulatory Policy? An Empirical Investigation of Chevron, 73 U. CHI. L. REV. 823, 832 (2006); Thomas J. Miles \& Cass R. Sunstein, The Real World of Arbitrariness Review, 75 U. CHI. L. REV. 761, 788-89 (2008).

10. See Sidney A. Shapiro \& Richard Murphy, Politicized Judicial Review in Administrative Law: Three Improbable Responses, 19 GEO. MASON L. REV. 319, 334-36 (2012); Sidney A. Shapiro \& Richard E. Levy, Judicial Incentives and Indeterminacy in Substantive Review of Administrative Decisions, 44 DUKE L.J. 1051, 1056-57 (1995). 
because of political pressure, such as legislative opposition if there is divided government. The political environment shifted for President Reagan, for example, when Ann Gorsuch - his first administrator of the Environmental Protection Agency ("EPA") - was forced to resign after being caught up in political scandal. ${ }^{11}$ The president was forced to appoint William Ruckelshaus, a former EPA administrator, who was committed to restoring EPA's credibility and effectiveness. ${ }^{12}$

In Figure 2, the position of the courts $(\mathrm{J})$ and the president $(\mathrm{P})$ are closer than in Figure 1 because it is more likely that judges will affirm the modification of a rule than it is they will accept its revocation, as Part II.B explains. Once again, the relative policy preferences of the other players can differ from those that are modeled in Figure 2. Regulatory beneficiaries, for example, may not be as opposed to the modification as Figure 2 indicates if the modification does not significantly reduce the protection available to them. Or the policy preference of regulated entities (E) may not be similar to that of the president because once again the costs of complying with the original rule may be largely sunk costs. Depending on its political makeup, Congress (C) might have a policy preference that is closer or more remote from the preferences of the president and regulated entities. Despite these and other permutations, the important point is that the case law is relatively favorable to the modification of a rule, and it is more so for the revocation of a rule. By comparison, as we come to next, legal doctrine is even more favorable, as a general matter, to rulemaking inaction.

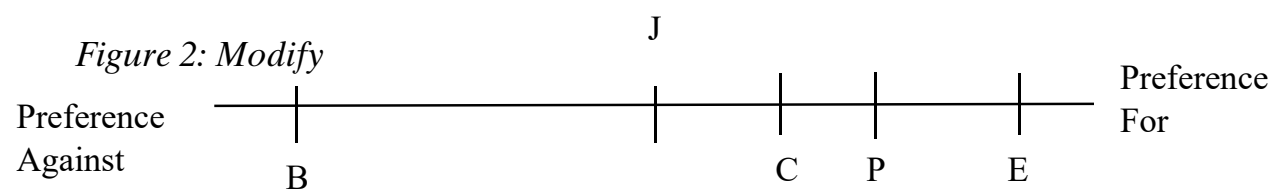

An agency's decision not to adopt new protective regulations is likely to be a winning strategy in terms of judicial review, as Part II.C explains. Like the previous diagrams, Figure 3 captures common strategic preferences of the agency and interested parties, but these can shift in a number of circumstances. For example, judicial patience for

11. JONATHAN LASH, KATHERINE GILLMAN \& DAVID SHERIDAN, A SEASON OF SPOILS: THE REAGAN ADMINISTRATION'S ATTACK ON THE ENVIRONMENT 81 (1st ed. 1984).

12. Daniel J. Fiorino, Streams of Environmental Innovation: Four Decades of EPA Policy Reform, 44 ENVTL. L. 723, 740 (2014). 
the failure to respond to a petition may not be as generous if the petition was filed in a previous administration, and a significant amount of time has elapsed prior to a new administration taking control of an agency..$^{13}$ Or an agency may decide to grant the petition and adopt a rule that is less stringent than a more zealous administration might adopt, as a tactic to raise the costs of replacing its rule in the new administration. All in all, none of the permutations belie the conclusion that judicial review is highly favorable to an administration that favors rulemaking inaction as a deregulatory strategy.

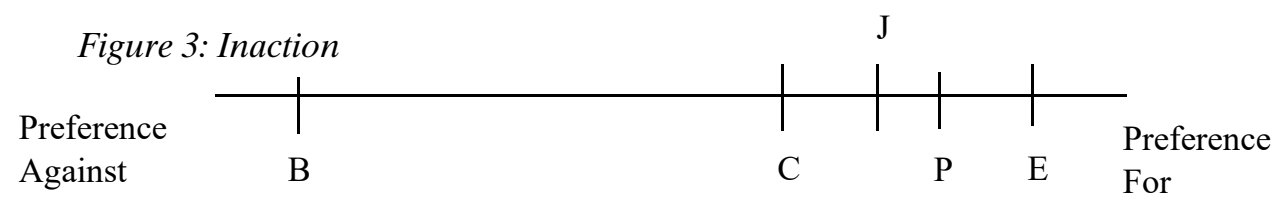

\section{THE ADMINISTRATIVE LAW OF DEREGULATION}

The previous description of an administration's strategic choices identifies differences in the prospect of judicial acceptance of rule revocation, modification, and inaction. Put simply, the courts are the least likely to affirm the revocation of a rule and the most likely to accept rulemaking inaction. This claim is made with recognition that for many lawyers and scholars, such as Professors Gellhorn and Robinson some forty years ago, "the rules governing judicial review have no more substance at the core than a seedless grape." ${ }^{\prime 14}$ Fair enough, but as Professor Schotland suggested, the scope of review at least establishes a "mood point[]" that forms the critical attitude with which a judge approaches an administrative decision. ${ }^{15}$ The law of inaction invites differing moods when it comes to revocation, modification, and inaction.

An administration can engage in inaction either by failing to start any new proregulatory rulemakings or by stalling proregulatory rules that it inherited. When an agency has failed to start new rules, regulatory beneficiaries cannot sue the agency for its inaction. The Supreme Court has instead held that their only remedy is to file a rulemaking petition and then seek judicial review if an agency rejects

13. See infra Parts III.C.3-4 (arguing that judges should apply more rigorous review to rulemaking inaction).

14. Ernest Gellhorn \& Glen O. Robinson, Perspectives on Administrative Law, 75 COLUM. L. REV. 771, 780 (1975).

15. Roy A. Schotland, Scope of Review of Administrative Action, 34 FED. B.J. 54, 59 (1975). 
the petition or fails to respond in a timely manner. If an agency is slow walking a rule, regulatory beneficiaries can sue the agency over the delay.

\section{A. Revocation}

The mood when judges review the revocation of a rule is skepticism. As Motor Vehicle Mfrs. Ass'n of U.S., Inc. v. State Farm Mut. Auto. Ins. Co. ${ }^{16}$ established years ago, courts are to employ hard look review, which requires judges to determine if the rulemaking record supports the determination that a rule is not necessary to address the risk or problem established by an agency when it promulgated the rule in the first place. ${ }^{17}$ Unless the original agency was mistaken, or somehow circumstances have changed, it will be difficult for the revoking agency to overcome the previous rulemaking record.

In State Farm, the Justices were unanimous that the National Highway Traffic Safety Administration ("NHTSA") had failed to explain its decision to drop the requirement that automobile manufacturers install air bags in cars. In fact, the NHTSA had not offered any explanation whatsoever. ${ }^{18}$ But a majority of the Court also found that the agency had failed to adequately explain revoking the requirement automobile manufacturers install automatic seatbelts because there was a discrepancy between this choice and some of the evidence buried in the rulemaking record.$^{19}$ Whether or not a reviewing court will likewise scour the rulemaking record in other revocation cases, it is clear that the revoking agency must overcome the findings in the original rulemaking record that a rule-some rule-is necessary to protect the public, according to the agency's mandate.

Assuming that the agency originally had reliable evidence establishing that the rule addressed a risk to the public or some other need for regulatory protection, it will be necessary for the same agency to show that this finding was in error. Perhaps the agency earlier made a hash of its findings in this regard, but this seems unlikely if, as most often happens, the rule was affirmed on appeal after a court of appeals

16. Motor Vehicle Mfrs. Ass'n v. State Farm Mut. Auto. Ins. Co., 463 U.S. 29 (1983).

17. Id. at 29, 42-44 (1983) (establishing that a judge must verify that an agency "examine[d] the relevant data and articulate[d] a satisfactory explanation for its action including a 'rational connection between the facts found and the choice made" (quoting Burlington Truck Lines, Inc. v. United States, 371 U.S. 156, 168 (1962))).

18. Id. at 46 ("NHTSA apparently gave no consideration whatever to modifying the Standard to require that airbag technology be utilized.").

19. Id. at 54 . 
applied hard look review to affirm the agency's claim that the rule was necessary to prevent some risk or harm.

Alternatively, when the agency revokes the rule, it may claim that the previous agency regime lacked the legal authority to promulgate its rule. Again, since the original rule is in effect, it likely survived judicial review and a challenge to its legal authority to promulgate the rule if one was available to the plaintiff.

Still, if the agency's original rule prevailed at step two of Chevron, when it revokes the rule, the agency presumably could argue that its claim of lack of jurisdiction is also a plausible reading of its statutory authority. ${ }^{20}$ Assume, for example, that a court had affirmed the Clean Power Plant Rule promulgated in the Obama administration. The rule was based on a contested interpretation of EPA's authority under the Clean Air Act. ${ }^{21}$ Arguably, a later administration could revoke the rule by reading the same statutory language as not empowering it to issue such a rule. The Supreme Court has held that a prior agency interpretation of a judicial ruling on the meaning of a provision is prohibited only if the prior court decision holds that its construction follows the unambiguous terms of the statute and thus makes no room for agency discretion..$^{22}$ It is not clear how often this situation arises, but when it does, the revoking agency may be more successful in court than if its revocation is based on a claim that no risk or problem exists.

\section{B. Modification}

The mood when judges review the modification of a rule is more accommodating. As agencies can choose more than one regulatory policy that is not "arbitrary" and "capricious," 23 judges have the expectation that an agency can modify a rule by making a different set of calculations concerning which of several policy options it prefers. In other words, although judges apply hard look review to rulemaking modifications, judges expect that an agency can justify the withdrawal of a rule because the agency is not trying to overcome an earlier

20. See Chevron, U.S.A., Inc. v. NRDC, 467 U.S. 837, 863-64 (1984) ("An initial agency interpretation is not instantly carved in stone ... [T] [Te agency ... must consider varying interpretations and the wisdom of its policy on a continuing basis.").

21. See Jody Freeman \& David B. Spence, Old Statutes, New Problems, 163 U. PA. L. REV. 1, 41-42 (2014).

22. Nat'l Cable \& Telecomm. Ass'n v. Brand X Internet Servs., 545 U.S. 967, 982 (2005); Maislin Indus., U.S., Inc. v. Primary Steel, Inc., 497 U.S. 116, 131 (1990); see also United States v. Home Concrete \& Supply, 566 U.S. 478, 486 (2012).

23. 5 U.S.C. $\$ 706(2)(a)(2012)$. 
rulemaking record that establishes some type of regulation is necessary.

In FCC v. Fox Television Stations, Inc. ${ }^{24}$ for example, the Court reviewed a decision by the Federal Communications Commission ("FCC") concerning when a broadcaster violated a ban on "indecent broadcasts." ${ }^{25}$ After Congress prohibited "indecent" broadcasts ${ }^{26}$ the FCC adopted a policy that it would not hold broadcasters liable for "fleeting expletives." ${ }^{27}$ Then, the FCC decided that, although it would not impose sanctions on the broadcasters, it would no longer allow a fleeting-expletive safe harbor ${ }^{28} \mathrm{~A}$ majority of five Justices affirmed the new policy in a decision in an opinion written by Justice Scalia, who declared policy changes should not be subject to stricter review than the usual demand of a reasoned explanation..$^{29}$ As he wrote, the agency

need not demonstrate to a court's satisfaction that the reasons for the new policy are better than the reasons for the old one; it suffices that the new policy is permissible under the statute, that there are good reasons for it, and that the agency believes it to be better, which the conscious change of course adequately indicates. ${ }^{30}$

Although Justice Kennedy voted to affirm the new policy, he joined the dissenting Justices in requiring an explanation why the agency chose to reject the first policy in favor of the second. ${ }^{31}$ So, five members of the Court decided that an agency must not only justify the new rule, but also must justify the change in rules.

Even if this expectation does not survive in light of the new makeup of the Court, ${ }^{32}$ agencies should normally be able to meet this

24. FCC v. Fox Television Stations, Inc., 556 U.S. 502 (2009).

25. Id. at 505-07.

26. See Public Telecommunications Act of 1992, Pub. L. No. 102-356, § 16(a), 106 Stat. 949, 954 (1992) (codified as amended at 47 U.S.C. $\$ 303$ (2010)) (instructing the FCC to enforce a statutory ban on indecent broadcasts).

27. See Fox Television Stations, 556 U.S. at 508, 512 (explaining the evolution of agency policy).

28. Id. at $512-13$.

29. Id. at 514 .

30. Id. at 515 (emphasis in original).

31. Id. at 547 (Breyer, J., dissenting); id. at 535 (Kennedy, J., concurring) (explaining that an agency making a policy change "must explain why 'it now reject[s] the considerations that led it to adopt that initial policy" (quoting $i d$. at 550 (Breyer, J., dissenting)).

32. In Encino Motorcars v. Navarro, 136 S. Ct. 2117 (2016), the Court remanded a policy change by an agency because it failed to offer an adequate explanation for its new policy. Id. at 2126. Writing for the majority, Justice Kennedy neither cited Fox Television Stations nor did he mention that an agency must justify its later policy as better than the earlier one. See id. at 2125- 
expectation. A later agency can reasonably disagree with the original choice, and, if so, it should be able to explain its difference of opinion when it justifies a modified rule. After all, the agency has reasons for preferring the new rule, and there is no reason to think agency lawyers cannot explain those reasons.

\section{Inaction}

A judge's mood when reviewing agency inaction is that agency priority setting is above his or her pay grade. As a result, when compared to the revocation or modification of a rule, an agency can expect the courts will almost always permit inaction. As regulatory beneficiaries cannot sue agencies for inaction unless there is a mandatory duty to promulgate a regulation, which Congress seldom imposes, the only way to attack inaction is to petition an agency to promulgate a rule. A court, however, will apply extremely deferential review if an agency rejects a rulemaking petition out of respect for the agency's need for priority setting. Alternatively, if an agency has not responded to a rulemaking petition, or if it has been slow in developing a rule, judges normally are unwilling to order the agency to take immediate action because of the difficulty in determining whether an agency has been acting in good faith. Intervention is therefore warranted only in cases where it is strikingly obvious that the refusal to work on a rule or start one cannot be justified as a matter of allowable administrative choice.

1. Rulemaking Petitions. After the Supreme Court's decision in Norton v. Southern Utah Wilderness Alliance, ${ }^{33}$ a plaintiff cannot sue an agency for inaction without first filing a petition requesting that action. In Norton, the plaintiff had sued the Department of Interior ("DOI") for its failure to ban the use of off-road-vehicles ("ORV") in wilderness study areas. The question before the Court was whether the judge could compel the DOI to act under its legislative mandate to protect such areas. In an opinion by Justice Scalia, the Court's answer was a resounding "no."

The Administrative Procedure Act ("APA") is at the center of the Norton decision. It creates a cause of action to sue an agency for

26 (describing the applicable legal doctrine). Since, however, the agency did not offer an adequate justification for its later rule, there was no necessity to discuss an agency's obligation to defend the later rule as better than the earlier one.

33. Norton v. S. Utah Wilderness All., 542 U.S. 55 (2004). 
persons "adversely affected or aggrieved by agency action within the meaning of a relevant statute," ${ }^{34}$ empowering regulatory beneficiaries to sue an agency to test the legality of the agency's action. Although this suggests that a plaintiff can only sue if an agency does something ("aggrieved by agency action"), the APA oxymoronically defines "agency action" as including the "failure to act." 35 The plaintiff in Norton claimed the agency's mandate required it to protect wilderness study areas from environmental deterioration, and environmentalists asserted the "use of ORVs on federal land has negative environmental consequences, including soil disruption and compaction, harassment of animals, and annoyance of wilderness lovers. ${ }^{" 36}$ In Norton, the plaintiff therefore asked the Court to order the DOI to ban ORVs under the Court's authority in the APA to "compel agency action unlawfully withheld." 37

The Court asserted that the agency's failure to ban the vehicles was not "unlawfully withheld" because the agency did not have a mandatory duty to take this step. Although the Court agreed that the agency had been required by Congress to protect wilderness study areas, it found Congress had left it up to the agency to determine what steps were necessary to accomplish this goal..$^{38}$ This interpretation was necessary, Justice Scalia explained, because when Congress adopted the APA, it intended to continue the traditional mandamus remedy as it existed prior to the APA..$^{39}$ Under traditional mandamus, a court is only authorized to order a government official to take a specific action if Congress has mandated that action. Put simply, the Norton plaintiffs were asking the Court to do something it could not do.

34. 5 U.S.C. $\$ 702$ (2012). To meet this burden, a plaintiff must demonstrate that the interest it seeks to protect is "arguably within the zone of interests to be protected . . . by the statute . . in question.” Ass'n of Data Processing Serv. Orgs. v. Camp, 397 U.S. 150, 153 (1970); see also MatchE-Be-Nash-She-Wish Band of Pottawatomi Indians v. Patchak, 567 U.S. 209, 225 (2012) (finding that a plaintiff was within the "zone of interest" because the plaintiff's interests were not "so marginally related to or inconsistent with the purposes implicit in the statute that it cannot reasonably be assumed that Congress intended to permit the suit" (quoting Clarke v. Sec. Indus. Ass'n, 479 U.S. 388, 399 (1987)); Air Courier Conference of Am. v. Am. Postal Workers Union, 498 U.S. 517, 524-28 (1991) (inquiring into the context of a statutory provision and its legislative history to determine that the plaintiff was not in the zone of interests).

35. 5 U.S.C. $§ 551(13)$.

36. Norton, 542 U.S. at $60,66$.

37. 5 U.S.C. $\$ 706(1)$.

38. See Norton, 542 U.S. at 66.

39. See id. at 63. 
What all of this means is a plaintiff is not entitled to relief unless an agency has a legal obligation to adopt a rule, which would be true only in two instances. First, if Congress has required an agency to promulgate a rule, which sometimes happens,${ }^{40}$ a plaintiff can get relief if the agency has failed to do so. And second, the other possibility arises after the agency has denied a rulemaking petition. If the denial is not legally justified, a court can compel the agency to start a rulemaking process. ${ }^{41}$ But the courts apply a form of very deferential review when ruling on the legality of an agency's decision to deny a rulemaking petition.

2. Denial. An agency is likely to prevail when there is a judicial challenge to its denial of a rulemaking petition because judicial review is "“extremely limited" and "highly deferential." 42 As a typical statement of the scope of review indicates, "[a]s a general proposition, this court will compel an agency to institute rulemaking proceedings only in extremely rare instances." ${ }^{43}$ Let's call this "soft look" review. ${ }^{44}$ Because review is a "soft look," a court's mood is to accept, at face value, a plausible explanation why an agency denied a rulemaking petition. A court will normally affirm the denial if, in a rulemaking petition, the agency claims it has limited resources and other priorities, ${ }^{45}$ a rule is unnecessary to address a regulatory problem, ${ }^{46}$ it lacks the scientific information to formulate a law, ${ }^{47}$ or that there is no significant regulatory problem to be addressed. ${ }^{48}$

40. See, e.g., Clean Air Act Amendments of 1990, 42 U.S.C. $§ 7615 b(d)$ (requiring EPA to "promulgate, not later than 18 months after November 15, 1990, a system for issuing, recording, and tracking [the] allowances [that authorize emissions of acid rain precursors], which shall specify all necessary procedures and requirements for an orderly and competitive functioning of the allowance system").

41. See, e.g., Massachusetts v. EPA, 549 U.S. 497, 528 (2007) (holding that the Clean Air Act permits review of EPA's rejection of a rulemaking petition).

42. Id. at 527-28 (quoting Nat'l Customs Brokers \& Forwarders Ass'n of Am. v. United States, 883 F.2d 93, 96 (D.C. Cir. 1989)).

43. Ark. Power \& Light Co. v. ICC, 725 F.2d 716, 723 (D.C. Cir. 1984).

44. Cf. Elizabeth Magill \& Adrian Vermeule, Allocating Power Within Agencies, 120 YALE L.J. 1032, 1055 (2011) (noting that “'hard look' review can become 'soft look' review or even a rubber stamp for agency decisionmaking").

45. See, e.g., Wildearth Guardians v. EPA, 751 F.3d 649, 651 (D.C. Cir. 2014); Defs. of Wildlife v. Gutierrez, 532 F.3d 913, 921 (D.C. Cir. 2008); UAW v. Chao, 361 F.3d 249, 255-56 (3d Cir. 2004).

46. See, e.g., Compassion Over Killing v. FDA, 849 F.3d 849, 857 (9th Cir. 2017).

47. In re Int'l Chem. Workers Union, 830 F.2d 369, 372 (D.C. Cir. 1987).

48. See, e.g., Compassion Over Killing, 849 F.3d at 857 (finding that the FDA had broad discretion to enforce on a case-by-case basis rather than promulgating regulations where the 
Under soft look review, "[f]ederal courts rarely conduct meaningful judicial review of agency inaction." ${ }^{~} 99$ Two reasons explain the credulous nature of judicial review. First, lacking a rulemaking record, it is difficult for a plaintiff to contest the agency explanation. Since "hard look" review requires a judge to assess the agency's justification in light of the rulemaking record, looking for discrepancies or oversights, ${ }^{50}$ soft look review reflects the lack of a record to conduct hard look review. The record before a court consists of the plaintiff's rulemaking petition and the agency's letter or notice denying the petition, which gives a plaintiff only a limited opportunity to point to facts that overcome the agency's claims. ${ }^{51}$

Second, soft look review of rulemaking petitions reflects judicial attitudes about agency priority setting and the interests of regulatory beneficiaries. Because a rulemaking petition effectively attempts to trump agency priority setting, judges have been sympathetic to an administration's prerogative-having won the election - to determine how to use agency resources. More broadly, since the agency is doing nothing, it is a matter of "no harm, no foul." That regulatory beneficiaries have a type of legal right to be protected simply does not enter the judicial equation.

To be sure, however, agencies are not given carte blanche authority to reject a rulemaking petition. Thus, the courts will overrule the denial of a rulemaking petition when an agency erroneously claims it lacks the legal authority to start the requested rulemaking. ${ }^{52}$ Likewise, the agency is likely to lose the case if its explanation is not facially credible in light of the claims in the rulemaking petition. ${ }^{53}$

agency decided to prioritize other projects); Serv. Women's Action Network v. Sec'y of Veterans Affairs, 815 F.3d 1369, 1376 (Fed. Cir. 2016); Preminger v. Sec'y of Veterans Aff., 632 F.3d 1345, 1354 (Fed. Cir. 2011).

49. Michael A. Livermore \& Richard L. Revesz, Regulatory Review, Capture, and Agency Inaction, 101 GEO. L.J. 1337, 1381 (2013).

50. See Motor Vehicle Mfrs. Ass'n v. State Farm Mut. Auto. Ins. Co., 463 U.S. 29, 43 (1983).

51. The situation changes, however, when an agency declines to issue a rule after it completes the rulemaking record. See, e.g., Pub. Citizen Health Res. Grp. v. Auchter, 702 F.2d 1150, 1159 (D.C. Cir. 1983). As the court explained in Williams Natural Gas Co. v. FERC, there is a difference "between an agency's refusal to undertake a rulemaking (reviewable, if at all, under an exceedingly narrow standard), and its decision to terminate a docket after a substantial record has been compiled." 872 F.2d 438, 443 (D.C. Cir. 1989). At the end of the rulemaking process, the court noted, it had "a sufficient evidentiary basis for determining whether the Commission's ultimate decision was arbitrary and capricious or in contravention of the statute." Id.

52. See, e.g., Massachusetts v. EPA, 549 U.S. 497, 532 (2007).

53. See, e.g., Flyers Rights Educ. Fund v. FAA, 864 F.3d 738, $744-45$ (D.C. Cir. 2017). 
Finally, according to Massachusetts v. EPA,${ }^{54}$ an agency cannot justify its denial based on reasons unrelated to its statutory mission. ${ }^{55}$ The last limitation is discussed in more detail in Part III.A.

All things considered, administrative law is more favorable to an agency's decision to deny a rulemaking petition than it is to judicial review of a rulemaking modification or withdrawal. While review is not toothless, it is not searching, either. An agency might trip over its own feet in justifying the denial of a rulemaking petition, but agencies should be able to avoid this outcome in most cases by careful legal and policy work. If not, why make dubious argument when an agency can go years without answering it as the next Section indicates?

3. No Response. An agency has an obligation under the APA to respond to a rulemaking petition within a "reasonable" amount of time ${ }^{56}$ and this requirement is judicially enforceable. ${ }^{57}$ What is reasonable is not defined, and most courts use the multi-factor analysis established in Telecommunications Research \& Action Center v. FCC ${ }^{58}$ ("TRAC") to assess "whether the agency's delay is so egregious as to warrant mandamus." ${ }^{\circ 9}$ But the factors are not particularly helpful in determining the reasonableness of a delay because their comparative importance has never been established; moreover, it is unclear how many of the factors are necessary to find a delay has been

54. Massachusetts v. EPA, 549 U.S. 497 (2007).

55. See id. at 533.

56. 5 U.S.C. $§ 555($ b) (2012) (establishing an agency's duty "within a reasonable time ... to conclude a matter presented to it" (emphasis added)).

57. Section 706(1) of the APA authorizes a court to "compel agency action unlawfully withheld or unreasonably delayed." 5 U.S.C. § 706(1) (emphasis added). Section 551(13) defines "agency action" to include "failure to act." 5 U.S.C. $§ 551(13)$.

58. Telecomms. Research \& Action Ctr. v. FCC, 750 F.2d 70 (D.C. Cir. 1984).

59. Id. at 79. The TRAC case developed the factors as a summation of considerations that had been used in other cases to determine whether a delay was unreasonable within the meaning of the APA. According to this summary:

(1) the time agencies take to make decisions must be governed by a "rule of reason";

(2) where Congress has provided a timetable or other indication of the speed with which it expects the agency to proceed in the enabling statute, that statutory scheme may supply content for this rule of reason; (3) delays that might be reasonable in the sphere of economic regulation are less tolerable when human health and welfare are at stake; (4) the court should consider the effect of expediting delayed action on agency activities of a higher or competing priority; (5) the court should also take into account the nature and extent of the interests prejudiced by delay; and (6) the court need not "find any impropriety lurking behind agency lassitude in order to hold that agency action is "unreasonably delayed."”

Id. at 80 (citations omitted) (quoting Pub. Citizen Health Research Grp. v. FDA, 740 F.2d 21, 34 (D.C. Cir. 1983)). 
unreasonable. ${ }^{60}$ Furthermore, although one of the factors is whether Congress has established a deadline to respond to a petition, ${ }^{61}$ the courts are split whether the deadline is mandatory or precatory. ${ }^{62} \mathrm{At}$ the end of the day, judges "can use the TRAC analysis to support virtually any conclusion they want to reach." ${ }^{\prime 63}$

Using this test, judges are inclined to accept an agency's excuse that "it is too busy," at least until enough years pass that this excuse no longer appears credible. ${ }^{64}$ Judges are in an accommodating mood because they are in no position to assess the relative priorities of all the things the agency does. Perhaps the agency's explanation is in good faith and perhaps it is not. Although an agency may be acting strategically when it makes this claim, it is also possible that the claims are in good faith. If, for example, a petition asks EPA to promulgate a rule under the Clean Air Act to reduce ambient exposure to a chemical because it is pollutant, the agency must investigate the scientific and other evidence needed to make this complex determination. And then it must determine whether the risk to the people and the environment is greater than from other pollutants that the agency is currently regulating or may regulate in the future. All of this must be done while the agency balances its other commitments and accounts for the resources available to it in these days of shrinking agency budgets. ${ }^{65}$

60. Sant'Ambrogio, supra note 6, at 1412.

61. Id. at 1411 .

62. Compare In re United Mine Workers of Am. Int'l Union, 190 F.3d 545, 551 (D.C. Cir. 1999) ("Our conclusion that the Secretary has violated the deadline set forth in the Mine Act does not end the analysis.... [W] e must continue our analysis of the remaining TRAC factors to determine whether mandamus is appropriate in this case."), with Forest Guardians v. Babbitt, 174 F.3d 1178, 1190-91 (10th Cir. 1999) ("[W]hen an entity governed by the APA fails to comply with a statutorily imposed absolute deadline, it has unlawfully withheld agency action and courts, upon proper application, must compel the agency to act.").

63. Sant'Ambrogio, supra note 6, at 1413.

64. See, e.g., In re Core Commc'ns, Inc., 531 F.3d 849, 857 (D.C. Cir. 2008) (finding that a six-year delay in issuing a justification for a rule after the rule was remanded without vacation was unreasonable); In re Am. Rivers \& Idaho Rivers United, 372 F.3d 413, 419-20 (D.C. Cir. 2004) (identifying that a failure to respond to rulemaking petition in six-plus years is unreasonable); In re United Mine Workers, 190 F.3d at 551-54 (noting that the court ordered an agency to produce timetable for promulgating final rule after an eight-year delay); Forest Guardians, 174 F.3d at 1193 (finding a four-year delay in promulgating a rule to be unreasonable in light of one-year statutory deadline for promulgation); Pub. Citizen Health Research Grp. v. Brock, 823 F.2d 626, 629 (D.C. Cir. 1987) (noting that a five-year delay in promulgating a final rule "treads at the very lip of the abyss of unreasonable delay").

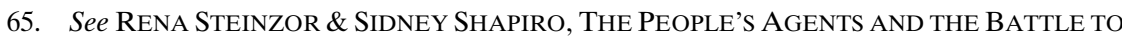
Protect the American Public: Special InTERESTs, Government, and Threats to HEALTH, SAFETY, AND THE ENVIRONMENT 65-67 (2010) (documenting budget cuts at health and safety agencies). 
Thus, in an APA irony, an agency can "respond to a petition for rulemaking designed to remedy indefinite agency delay with more indefinite agency delay." ${ }^{66}$ For any agency with a deregulatory agenda, current doctrine offers an opportunity to delay a response for much of an entire administration, if not the whole four years. Even when a court begins to doubt that the agency's justification is valid, it will nonetheless ask the agency to develop a schedule for responding, rather than order it to do so, a result that buys the agency even more time ${ }^{67}$ Though this remedy eventually forces an agency to cough up a response, it also offers the agency more time to delay as part of a deregulatory strategy.

4. A Slow Walk. Agencies in a new presidential administration will inherit some rules that were started by their predecessors. An agency committed to deregulation has two options for existing rules in the pipeline. It can withdraw them from the rulemaking, but as indicated previously, this strategy may not be successful if the agency has already developed a rulemaking record. Or it can slow down the development of existing regulatory rules to the average speed of an tortoise, ${ }^{68}$ which pretty much guarantees that nothing will happen for several years. ${ }^{69}$

Courts will evaluate claims of unreasonable delay in the completion of a rule in light of the extent of the delay, the nature of the agency's statutory mandate, the consequences of the delay, and the validity of the agency's reasons why it is taking so long. ${ }^{70}$ Once again, the vagueness of these factors and the failure to decide the significance of each factor as compared to the others allows judges to accept even long delays if they are so inclined. And they are. Judges have the same reluctance to interfere with how an agency balances its priorities and resources concerning the development of existing rules as they do

66. Sidney A. Shapiro \& Richard Murphy, Constraining White House Political Control of Agency Rulemaking Through the Duty of Reasoned Explanation, 48 U.C. DAVIS L. REV. 1457, 1487 (2015).

67. See Nat'l Cong. of Hispanic Am. Citizens (El Congreso) v. Marshall, 626 F.2d 882, 891 (D.C. Cir. 1979); cf. Nat'l Res. Def. Council v. Train, 510 F.2d 692, 712 (D.C. Cir. 1975) (stating that "[t]he courts cannot responsibly mandate flat guideline deadlines when the Administrator demonstrates that additional time is necessary" to ensure compliance with the statute).

68. Jacob Reis, How Fast Does A Turtle Run?, CUTENESS, https://www.cuteness.com/article/ how-fast-does-turtle-run [https://perma.cc/R7YA-CCTZ] ("While the average turtle can only 'run' 3 or $4 \mathrm{mph}$, there are some who are much slower.").

69. See supra note 8 and accompanying text.

70. See In re Int'l Chem. Workers Union, 958 F.2d 1144, 1149 (D.C. Cir. 1992). 
concerning the failure to respond to a rulemaking petition. ${ }^{71}$ Even if a court finds that a delay has been unreasonable, or that at least borders on the unreasonable, the court will likely order the agency to establish a timetable for completion of the regulation. ${ }^{72}$ But even then, the court may allow the agency to extend the earlier deadlines. ${ }^{73}$

\section{ENHANCED ACCOUNTABILITY}

The process of judicial review is the most likely to accept deregulation by rulemaking inaction, less likely to accept the modification of rules, and the least likely to accept the revocation of a rule. While this asymmetry allows judges to avoid potential interference with agency priority setting, it does so at the cost of enabling the strategic use of rulemaking inaction as a tool of deregulation. Accordingly, when it comes to establishing accountability for using rulemaking inaction as deregulation, administrative law in effect defers to electoral politics to provide that accountability.

There are two significant problems with this judicial surrender. First, it abandons the traditional role of administrative law in legitimizing agency action by constraining the operation of politics within the rulemaking process, and electoral accountability, which exists more in theory than in practice, does not make up for this shortfall. Second, even if the president is accountable at some broad level for the policies of his administration, he enjoys considerable insulation that shields him from observation by many voters when he acts to deregulate. As a result, when a deregulatory administration takes office, there may be no effective check on the strategic use of rulemaking inaction as a deregulatory strategy.

Because of these defects, the courts should abandon their overly deferential judicial review of rulemaking inaction. A less deferential

71. See, e.g., Oil, Chem. \& Atomic Workers Union v. OSHA, 145 F.3d 120, 123 (3d Cir. 1998) ("Distilled to its essence, this petition ... would have us intrude into the quintessential discretion of the Secretary of Labor to allocate OSHA's resources and set its priorities."); Pub. Citizen Health Research Grp. v. Brock, 823 F.2d 626, 629 (D.C. Cir. 1987) ("This court should intervene to override agency priorities and timetables only in the most egregious of cases.") (emphasis in original).

72. See, e.g., In re Int'l Chem. Workers Union, 958 F.2d at 1150; Oil, Chem. \& Atomic Workers Int'l Union v. Zegeer, 768 F.2d 1480, 1488 (D.C. Cir. 1985).

73. See, e.g., Nat'l Cong. of Hispanic Am. Citizens (El Congreso) v. Marshall, 626 F.2d 882, 888 (D.C. Cir. 1979) ("[T] he timetables ... are not etched in stone ... [and] the Secretary has authority to delay development of a standard ...."). 
approach need not unduly intrude on agency priority setting, and even if that cost cannot be entirely avoided, more aggressive review is justified by the courts' obligation to review political interference with an agency's responsibility to protect the public.

\section{A. Legal Civics}

The courts' use of uber-deference to review rulemaking inaction is a judicial abandonment of the traditional role of administrative law of legitimizing agency action by constraining the operation of politics. The origin of this obligation is the judiciary's role in our constitutional system of ensuring the rule of law, which in this context requires implementing Congress' commitment to protect the public and the environment as an agency's statutory mandate requires.

Administrative law has long been the way we try to fit the "round peg' of administrative government into the 'square hole' of the nation's constitutional culture." 74 Because the attributes of modern administrative government are missing from basic constitutional design, we have been on a decades-long effort to reinterpret our legal culture to accommodate positive government on a massive scale..$^{75}$ The contribution of administrative law to this effort was captured by Frank Newman's observation that administrative law is "'Legal' Civics, no more, no less." ${ }^{.76}$ At bottom, the obligation that an agency must act consistently with its statutory mandates is what makes administrative law into "legal" civics.

Despite the difficulty of verifying this consistency with vague and ambiguous legislative mandates, the process of verification legitimizes agency action by associating it with a democratic act - the enactment of a law. It may well be the situation that Congress, by using vague and ambiguous language, has delegated to agencies a generous policy space in which to operate. The question is not whether the agency is carrying out the intent of Congress, which cannot be fully determined. Rather, it is whether the agency is acting within the confines of its delegation. If so, judicial confirmation makes the agency action democratic, as well.

74. Sidney A. Shapiro, Pragmatic Administrative Law, 5 ISSUES IN LEGAL SCHOLARSHIP: THE REFORMATION OF AMERICAN ADMINISTRATIVE LAW 1, 3 (2005).

75. For an overview of this history, see generally JAMES O. FREEDMAN, CRISIS AND LEGITIMACY: THE ADMINISTRATIVE PROCESS AND AMERICAN GOVERNMENT (1978).

76. WAlter GellHorn \& Clark Byse, Administrative LAW: CASES AND COMMENTS xvii (6th ed. 1974) (quoting Professor Frank C. Newman). 
On one hand, both State Farm and Massachusetts v. EPA confirmed that administrative law is legal civics by interpreting the relevant statutory mandates as floors of obligation to protect statutory beneficiaries. On the other hand, the Court's endorsement of extreme deference in the review of agency action in Massachusetts $v$. EPA belies this commitment.

When the Supreme Court reviewed NHTSA's decision to revoke a protective rule, it insisted that it offer "a satisfactory explanation for its action including 'a rational connection between the facts found and the choice made."'77 The Court therefore placed a floor on deregulation by requiring that an agency be able to justify a rule revocation as consistent with its duty to protect people or the environment.

This is not all. The Court refused to credit that NHTSA was fulfilling a campaign promise of President Reagan. It did not matter to the Court that NHTSA was responding to President' Reagan's efforts to bring regulatory relief to the automobile industry, one of his prominent campaign promises. ${ }^{78}$ By requiring the agency to justify its revocation as consistent with its statutory mandate, the Court instead endorsed the traditional role of administrative law as a constraint on politics.

Finally, but hardly least of all, the Court rejected the idea that deregulatory actions are entitled to more judicial deference because they remove government restrictions on people or property. Prior to the State Farm decision, a range of "litigants and commentators . . . argued that [the courts] should review deregulation less [vigorously] than they" review the promulgation of a new rule. ${ }^{79}$ To the contrary, according to the Court, "[i]f Congress established a presumption from which judicial review should start, that presumption-contrary to petitioners' views - is not against safety regulation, but against changes in current policy that are not justified by the rulemaking record." ${ }^{80}$

Two aspects of Massachusetts v. EPA are noteworthy regarding legal civics. First, the Court again explicitly rejected compliance with presidential preferences as a justification for inaction when those

77. Motor Vehicle Mfrs. Ass'n v. State Farm Mut. Auto. Ins. Co., 463 U.S. 29, 43 (1983) (quoting Burlington Truck Lines, Inc. v. United States, 371 U.S. 156, 168 (1962)).

78. Jerry L. Mashaw \& David L. Harfst, From Command and Control to Collaboration and Deference: The Transformation of Auto Safety Regulation, 34 YALE J. ON REG. 167, 188 (2017).

79. Merrick B. Garland, Deregulation and Judicial Review, 98 HARV. L. REV. 505, 513 (1985).

80. State Farm, 463 U.S. at 42 (emphasis in original). 
preferences do not relate to an agency's obligation to protect people or the environment. And second, it refused to extend the presumption against judicial review of enforcement decisions to agency decisions not to regulate. This underlined that the courts must have a role in protecting the interests of regulatory beneficiaries concerning rulemaking inaction. Unfortunately, the Court did not recognize the inconsistency of highly deferential review with this commitment.

The petitioners in Massachusetts $v$. EPA had filed a rulemaking petition asking EPA to regulate the emission of four greenhouse gases using its authority under the Clean Air Act. ${ }^{81}$ After EPA rejected the petition, the Court reversed because EPA "offered no reason[ed] explanation" of its denial. ${ }^{82}$ EPA had argued that it lacked the legal jurisdiction for such a regulation, but the Court found no legal basis to uphold that claim. ${ }^{83}$ As an alternative, EPA offered "a laundry list of reasons not to regulate," but the Court objected that EPA's "reasons for action or inaction must conform to the authorizing statute." 84

The Court noted that EPA claimed that if it regulated it "might impair the President's ability to negotiate with 'key developing nations' to reduce emissions," and that regulation would "reflect 'an inefficient, piecemeal approach to address the climate change issue." 85 The problem with these reasons, the Court stated, is that "they have nothing to do with whether greenhouse gas emissions contribute to climate change," $" 86$ a determination that EPA was required by statute to make. ${ }^{87}$

By its decision, the Court was enforcing both a ceiling and a floor that cabined EPA's policymaking space. Just as EPA could not exceed the legal authority delegated by Congress, it also could not avoid its statutory obligation except for priority setting related to its mission to protect people and the environment.

Cass Sunstein and Adrian Vermeule argue that the Court could not have intended the offered reading because it would prohibit an agency from justifying the denial of a petition on resource grounds. ${ }^{88}$ It

\footnotetext{
81. Massachusetts v. EPA, 549 U.S. 497, 510 (2007).

82. Id. at 534 .

83. Id. at 528-32.

84. Id. at 533 .

85. Id. (citations omitted).

86. Id.

87. Id. at 532-33.

88. Sunstein \& Vermeule, supra note 6, at 170.
} 
is not evident, however, why agencies are restricted in this way. Although Congress has tasked an agency with an affirmative obligation to implement the protections it has identified in its mandate, surely it also understood that agencies will have to make choices in terms of priority setting. As Shep Melnik has noted, agencies "are almost always given huge, even utopian, goals and are then saddled with a large number of constraints that prevent them from achieving these goals efficiently - or even at all." ${ }^{89}$ Congress, for example, has ordered EPA to "maintain the chemical, physical and biological integrity of the Nation's waters, ${ }^{90}$ to ensure waters are fishable and swimmable, ${ }^{91}$ and to terminate discharge of pollutants. ${ }^{92}$ Only legislators willfully ignorant of bureaucratic realities could expect that EPA could fulfill those goals all at once as opposed to through a gradual, steady progress.

Moreover, legitimate priority setting can be in service of that agency mandate. As agencies have limited resources, they are likely to be more successful in protecting people and the environment by working on a limited number of rules than indiscriminately working on more rules and not advancing any of them. The choice, then, inevitably involves considering resource limitations, legal constraints, and the agency's political environment. The problem with rulemaking inaction is not that agencies defend it as a matter of priority setting. The problem is that judicial review makes little or no effort to verify that the reasons cited by the agency are not a fig leaf for a strategy of deregulation.

A second aspect of Massachusetts v. EPA also endorses the role of administrative law as a constraint on politics. After Heckler $v$. Chaney, ${ }^{93}$ it was unclear for a time whether the presumption against judicial review of "enforcement" decisions created in the case included judicial review of an agency's decision to reject a rulemaking petition. Although the priority setting decisions made concerning enforcement and the rejection of a rulemaking petition require similar assessments of agency priorities, the Court recognized that the rulemaking situation

89. R. Shep Melnick, The Political Roots of the Judicial Dilemma, 49 ADMIN. L. REV. 585 , 586 (1997).

90. 33 U.S.C. § 1251(a) (2012).

91. Id. § 1251(a)(1).

92. Id. § 1251(a)(2).

93. Heckler v. Chaney, 470 U.S. 821 (1985). 
was different because regulatory beneficiaries have a statutory right to protection under an agency's mandate.

Heckler declined to review the Food and Drug Administration's ("FDA") rejection of a petition from prisoners on death row asking the agency to use its enforcement powers to stop the use of drugs for lethal injections to carry out the death penalty. ${ }^{94}$ The plaintiffs had argued that the FDA's statutory mandate required it to act, but the Court rejected their argument by calling on a presumption against judicial review of agency enforcement actions. ${ }^{95}$

Some of the reasons the Court cited for a presumption against review of enforcement decisions could just as easily apply to judicial review of the rejection of a rulemaking petition. Judicial review of enforcement priorities was "unsuitab[le]" because these decisions "often involve[d] a complicated balancing of a number of factors which are peculiarly within [an agency's] expertise ${ }^{~} 96$ and because a decision not to prosecute does not involve the government's "exercise [of] its coercive power over an individual's liberty or property rights." same might be said concerning the rejection of a rulemaking petition. The rejection, in a broad sense, is a decision about how best to "enforce" an agency's legislative mandate. And like a decision not to prosecute, the rejection of a rulemaking petition does not involve the government's use of its coercive power.

The Court in Massachusetts v. EPA did not share this view, however. It distinguished the two situations in this way:

In contrast to nonenforcement decisions, agency refusals to initiate rulemaking 'are less frequent, more apt to involve legal as opposed to factual analysis, and subject to special formalities, including a public explanation.' They moreover arise out of denials of petitions for

94. Id. at $837-38$.

95. Id. at 836. The Court attributed the presumption to Congress on the ground that when it passed the Administrative Procedure Act legislators were aware of the long tradition of prosecutorial discretion. See id. at 832 ("[W]e believe that the Congress enacting the APA did not intend to alter that tradition" of agency discretion.).

96. Id. at 831 .

97. Id. at 832 (emphasis in original). The Court also found that there was no "focus for judicial review" because, unlike in enforcement decisions, the agency did not "exercise[] its power in some manner." Id. The fourth reason was that an agency's decision not to take an enforcement action was similar to that of a "prosecutor ... not to indict-a decision which has long been regarded as the special providence of the Executive Branch, inasmuch as it is the Executive who is charged by the Constitution to 'take Care that the Laws be faithfully executed." Id. (quoting U.S. CONST. art. II, § 3). 
rulemaking which (at least in the circumstances here) the affected party had an undoubted procedural right to file in the first instance. ${ }^{98}$

Yet, the Court did not explain how these factual differences were related to the rationale in Heckler. Put differently, why does the balance shift in favor of judicial review in light of these differences?

It may be that the Court was saying that an agency requires more discretion when making enforcement decisions than in decisions about rulemaking petitions, given the differences that the Court identified. ${ }^{99}$ But the Court also mentions that these cases "arise out of denials of petitions for rulemaking which (at least in the circumstances here) the affected party had an undoubted procedural right to file in the first instance." 100 In other words, Congress gave regulatory beneficiaries the right to petition for protection, and as the Court went on to say in its opinion, the agency has an obligation to provide that protection unless it can give acceptable reasons why it cannot do so. ${ }^{101}$

At the same time, while it did not immunize rulemaking inaction decisions from judicial review, the Court continued the extreme deference that is used in rulemaking inaction cases. ${ }^{102}$ Its recognition that enforcement and rulemaking inaction decisions involve priority setting led it to this unfortunate compromise. Litigants can sue regarding inaction, but agencies are entitled to extreme deference. But, as established earlier, this review is essentially no review at all. ${ }^{103}$ Thus, by default, the Court left regulatory beneficiaries with political accountability as the sole protection of their interests. This is, as it turns out, little to no protection in administrations that use rulemaking inaction as a deregulatory strategy.

Some readers might object that inaction is not really a deregulatory strategy because, after all, there is no revocation or modification of an existing regulation. Once you consider that Congress establishes both a floor and ceiling when it adopts a regulatory mandate, however, inaction is properly considered deregulation. Congress has obligated an agency to act to protect the

98. Massachusetts v. EPA, 549 U.S. 497, 527 (2007) (citations omitted).

99. See Jody Freeman \& Adrian Vermeule, Massachusetts v. EPA: From Politics to Expertise, 2007 SUP. CT. REV. 51, 96-97 (2007) (suggesting that the differences were related to "worry that agencies must have discretion to allocate resources on cost-benefit grounds").

100. Massachusetts v. EPA, 549 U.S. at 527.

101. See id. at 534 (finding that EPA "offered no reasoned explanation" for its rejection).

102. Id. at 527-28.

103. See supra Part II.C (discussing the very deferential review applied by courts in the rare instances that plaintiffs are entitled to relief). 
public. It has not been indifferent between regulating and not regulating. When an agency fails to regulate, it is defying its legislative mandate, and that act is properly considered deregulatory unless the agency can establish that it has higher priorities in terms of protecting people and the environment.

\section{B. "The Unbearable Lightness" 104 of Political Accountability}

State Farm and Massachusetts v. EPA create an expectation that an agency's refusal to regulate must be defended as consistent with its statutory mandate. Whatever has motivated an agency, including presidential preferences, the agency must justify its actions as consistent with its statutory mandate. Priority setting is a legitimate aspect of that mandate. Although agencies have an obligation to protect regulatory beneficiaries, that mandate is facilitated when agencies make reasonable choices as to how best to implement it.

The challenge for the courts concerning rulemaking inaction is how to verify that an agency has made reasonable choices concerning priority setting. Under the current approach, the courts make no serious effort to determine whether agencies' claims about priority setting are reasonable. The court's use of uber-deference takes them entirely out of the picture as an agent of accountability.

This defection results in a default to presidential accountability to protect regulatory beneficiaries. For some scholars, this defection is appropriate. They contend an agency should be able to rely on presidential preferences as part of its justification for an action. ${ }^{105}$ According to this argument, because the president is accountable to the electorate, the legitimacy of administrative law is thus strengthened, not weakened. ${ }^{106}$ In addition, they justify judicial

104. With a nod to Milan Kundera, THE UnBEARABLE LiGHTNESS OF BEING (1984).

105. See, e.g., CHRISTOPHER F. EDLEY, JR., AdMINISTRATIVE LAW: RETHINKING JUdiCIAL CONTROL OF BUREAUCRACY 192 (1990) (contending that courts should "credit politics as an acceptable and even desirable element of decision making"); Kathryn A. Watts, Proposing a Place for Politics in Arbitrary and Capricious Review, 119 YALE L.J. 2, 8 (2009) (proposing that courts should accept certain "political influences" in favor of a rule's validity so long as they "are openly and transparently disclosed in the agency's rulemaking record"). See generally Nina A. Mendelson, Disclosing "Political” Oversight of Agency Decision Making, 108 MICH. L. REV. 1127 (2010) (documenting presidential supervision of agencies and resulting changes in agency rules while arguing for greater transparency of this influence).

106. See, e.g., Elena Kagan, Presidential Administration, 114 HARV. L. REV. 2245, 2380 (2001) (proposing that courts relax hard look review if "demonstrable evidence shows that the President has taken an active role in, and by so doing has accepted responsibility for, [an] administrative decision"). 
recognition of presidential preferences as consistent with constitutional arrangements that put the president is charge of the federal government. ${ }^{107}$

Other scholars object that this move would weaken the traditional role of administrative law in legitimizing agency regulatory action. Specifically, their animating concern is that it would result in constraining the operation of politics within the rulemaking process. ${ }^{108}$ They also doubt the efficacy of presidential accountability to prevent the president from doing the bidding of special interest groups in supervising agency action. ${ }^{109}$

Concerns about presidential accountability are well founded for three reasons. First, as the political science literature warns us, the actions of elected officials are often hidden from voters, a condition that is described as "slack." 110 When elected officials have slack, this invisibility allows them to avoid electoral control by voters and do the bidding of special interest groups to the detriment of their constituents. ${ }^{111}$ Unsurprisingly, "the president has the incentive and

107. The unitary executive "allocates the power of law execution and administration to the President alone." Steven G. Calabresi \& Saikrishna B. Prakash, The President's Power to Execute the Laws, 104 YALE L.J. 541, 549 (1994). As result, even if Congress has expressly delegated rulemaking authority to an agency, the president can decide issues regarding the timing or substance of rulemaking. See id. at 581-82.

108. See, e.g., Mark Seidenfeld, The Irrelevance of Politics for Arbitrary and Capricious Review, 90 WASH. U. L. REV. 141, 144-45 (2012) (taking the position that "although politics may be a legitimate motivation for agency regulation, it should be irrelevant to judicial review of that regulation"). See generally Jodi L. Short, The Political Turn in American Administrative Law: Power, Rationality, and Reasons, 61 DUKE L.J. 1811 (2012) (rejecting political reason-giving models for reform).

109. See Glen Staszewski, Political Reasons, Deliberative Democracy, and Administrative Law, 97 IOWA L. REV. 849, 852, 898-99 (2012) (objecting to the courts giving positive weight to political reasons in arbitrary and capricious review because it undermines electoral accountability).

110. Michael E. Levine \& Jennifer L. Forrence, Regulatory Capture, Public Interest, and the Public Agenda: Toward a Synthesis, 6 J.L., ECON. \& ORG. 167, 185 (1990) (defining “slack"). The authors explain:

High information, monitoring and organization costs create "slack," which shields officials from accountability to the general polity. Members of the general polity ordinarily do not have an incentive to learn issues well enough to comprehend their impact or to monitor and discipline the behavior of all those officials whose acts might affect them. This slack can be used by a regulator or her political sponsor to pursue officeholding self-interest... by pursuing regulatory policies that benefit special interests.

Id.

111. Id. at 176-77; Joseph P. Kalt \& Mark A. Zupan, Capture and Ideology in the Economic Theory of Politics, 74 AM. ECON. REV. 279, 282-84 (1984) (observing that any "slack" given to political representatives can result in behavior that is independent of their constituents' 
ability to hide" actions taken at the behest of special interest groups. ${ }^{112}$ But, even if voters have some idea about the president's tactics, it seems farfetched that many would understand the strategic use of rulemaking inaction as a tool of deregulation, and in particular, how inaction can delay the adoption of protective rules for years and years. ${ }^{113}$

Second, even if voters cop on to a president's tactics, they will have to wait until the next election to correct a president's commitment to inaction, which can postpone protective actions by five or more additional years even after a pro-protective president is elected. ${ }^{114}$ In a president's second term, electoral accountability is even more attenuated, making it, to the extent it does exist, a weak protection of the interests of regulatory beneficiaries. It is well established that Americans can pay a high price for that delay, both in dollars and lost lives. ${ }^{115}$

Finally, it is not clear that voters will be able to hold a president accountable in light of dysfunction in the political system, such as the electoral college, campaign finance laws that permit unlimited contributions by the wealthy, political gerrymandering, and voter irrationality which can give the upper hand to interests opposed to government regulation. Because of the electoral college, a nominee can

accountability).

112. Lisa Schultz Bressman, Beyond Accountability: Arbitrariness and Legitimacy in the Administrative State, 78 NYU L. REV. 461, 506 (2003).

113. It is true that if a president campaigns on promising less regulation, voters will have this information, but voters' capacity to understand and process the information is likely to be limited as explained above.

114. See supra note 8 and accompanying text.

115. See, e.g., CATHERINe O'Neill, Amy Sinden, Rena STEInzor, JAMEs Goodwin \& Ling-YeE HuANG ET AL., THE HidDen Human AND ENVIRONMENTAL COSTS OF REGULATORY DELAY 1 (2009), http://www.progressivereform.org/articles/CostofDelay_907.pdf [http://perma.cc/8ZNT-GRGT] (discussing how "[e]ach year dozens of workers are killed, thousands of children harmed, and millions of dollars wasted because of unjustifiable delays in federal regulatory action."); Ariel Katz, Pharmaceutical Lemons: Innovation and Regulation in the Drug Industry, 14 MiCH. TELECOMM. \& TECH. L. REV. 1, 5 (2007) (finding that "as a result of the cost and delay imposed by the regulatory approval process, thousands of potential new drug beneficiaries would die or unnecessarily suffer"); Ruth Ruttenberg, Jonathan Cardi \& Estye Fenton, The Taxpayers' Burden from Product-Related Harm, 21 KAN. J.L. \& PUB. POL'Y 121, 121 (2011) (noting that "[h]undreds of billions of dollars are spent every year in the public sector as a result of death, injury, and illness associated with products"); Sidney Shapiro, Ruth Ruttenberg \& Paul Leigh, The Social Costs of Dangerous Products: An Empirical Investigation, 18 CORNELL J.L. \& PUB. POL'Y 775 (2009) (calculating empirical estimates of the costs to consumers of product and other injuries that are not prevented). 
win the presidency and still lose the popular vote, ${ }^{116}$ an anomaly that can prevent the majority of Americans from holding a president accountable for the president's deregulatory policies. ${ }^{117}$ After Citizens United, ${ }^{118}$ the capacity of wealthier Americans and corporations to spend unlimited amounts of money to support a president committed to deregulation increases their influence over the political process. ${ }^{119}$ Political gerrymandering can distort the election of members of Congress, allowing the party of a deregulatory president to control the House of Representatives despite losing the national vote for members of the House. ${ }^{120}$ Finally, the opponents of a president who engages in deregulation must overcome the irrationality of voters that can lead

116. President George W. Bush, for example, was elected president by the Electoral College on a vote of 271 to 266 although his opponent, Al Gore, won 51 percent of the popular vote. 2000 Presidential Electoral and Popular Vote, FED. EleCtion COMMISSION (Dec., 2001), https://transition.fec.gov/pubrec/fe2000/elecpop.htm [https://perma.cc/27ZY-ZH3Q]. More recently, President Donald Trump received 304 votes to Hillary Clinton's 227 votes in the electoral college, FED. ELECTION COMMISSION, OFFICIAL 2016 GENERAL ELECTION Votes 1 (Jan. 30, 2017), https://transition.fec.gov/pubrec/fe2016/2016presgeresults.pdf [https://perma.cc/ SYX2-CPWK], although Clinton received almost three million more votes in the popular election. Id. at 2, 6; Presidential Election Results: Donald J. Trump Wins, N.Y. TIMES (Aug. 9, 2017, 9:00 AM ET), https://www.nytimes.com/elections/2016/results/president [https://perma.cc/ RM5C-EQK8.

117. See Akhil Reed Amar, A Constitutional Accident Waiting to Happen, 12 CONST. COMMENT. 143, 143, 145 (1995) (noting that "dreaded specter of a clear popular loser becoming the electoral college winner" is a "constitutional accident waiting to happen"); John B. Anderson, The Electoral College Flunks the Test in an Age of Democracy, AM. B. Ass'N: Hum. RTS. MAG. (June 30, 2017), https://www.americanbar.org/groups/crsj/publications/human_rights_ magazine_home/human_rights_vol32_2005/spring2005/hr_spring05_college [https://perma.cc/ KR8P-GCJN] (calling for "[d]irect democracy . . . at home within the borders of the American republic").

118. Citizens United v. Fed. Election Comm'n, 558 U.S. 310 (2010).

119. See Tim Bakken, Constitutional Rights and Political Power of Corporations After Citizens United: The Decline of Citizens and the Rise of Foreign Corporations and Super PACs, 12 CARDOZO PUB. L. POL'Y \& ETHICS 119, 120 (2013) (concluding that "Citizens United creates immense additional corporate influence over the U.S. political process"); Robert Weissman, Commentary, Let the People Speak: The Case for a Constitutional Amendment to Remove Corporate Speech From the Ambit of the First Amendment, 83 TEMPLE L. REV. 979, 995 (2011) (observing, based on empirical information, that Citizens United "empowered a tiny number of organizations, relying on a tiny number of corporate and superwealthy contributors-many hidden behind a veil of secrecy - to raise and spend huge sums of money and exert a very substantial impact on the campaigns").

120. See Bernard Grofman, Criteria for Districting: A Social Science Perspective, 33 UCLA L. REV. 77, 112 (1985) (finding the invidious discrimination "against the candidates of a political party is to effectively disenfranchise the voters who support the positions espoused by that party's candidates, to dilute the importance of their views in the halls of the legislature"); Richard E. Levy, The Nonpartisanship Principle, 25 KAN. J.L. \& PUB. POL'Y 377, 392-93 (2016) (demonstrating how, as a result of gerrymandering, the Republican party can win more seats in the House of Representatives despite winning less than 50 percent of the national vote). 
them to favor polices like deregulation even though the voters are disadvantaged by the policy. ${ }^{121}$ Not for nothing did Winston Churchill observe "it has been said that democracy is the worst form of Government except for all those other forms that have been tried from time to time ...."122

Realistic appraisal of electoral accountability leads to the conclusion that presidents can use deregulation to reward regulated entities and their supporters for their political support, despite the fact that the president is elected by and represents the entire nation. As Lisa Schultz Bressman has pointed out, "[a]sserting that the President is more immune to factional pressure than Congress because of his national constituency only asserts that [he] is immune in a relative sense" and "serious questions exist as to whether the President is immune at all." "23

To be fair, scholars who would allow agencies to defend their actions based on presidential preferences are not completely trusting of electoral accountability. Katheryn Watts, for example, has proposed that courts should be more inclined to defer to an agency policy choice where the agency's reasons for that choice include "the president wanted us to do this." ${ }^{124}$ At the same time, she would have courts reject agency reasons that reflect "raw politics or partisan politics." 25

As noted, administrative law has not chosen this path. ${ }^{126}$ Agencies can consider presidential preferences, but they still must "come up with reasoned justifications that can theoretically stand on their own regardless of which political actors might favor them." ${ }^{127}$ This traditional administrative limitation on politics respects the idea that

121. See Sherman J. Clark, Commentary, A Populist Critique of Direct Democracy, 112 HARV. L. REV. 434, 476 (1998) (observing the "[p]otentially troubling ... near-certainty that there are many issues voters do not understand well, or perhaps do not even realize are being decided"); Gary M. Lucas, Jr. \& Slavisa Tasic, Behaviroal Public Choice and the Law, 118 W. VA. L. REV. 199, 212 (2015) (noting that "irrationality opens up an opportunity for politicians, bureaucrats, and special interest groups to take advantage of voters" because "[i]rrational voters may not rationally discount propaganda and other appeals to emotion, making them susceptible to deceptive forms of persuasion").

122. The Worst Form of Government, INT'L CHURCHILL SOC'Y, https://winstonchurchill.org/ resources/quotes/the-worst-form-of-government [https://perma.cc/V35F-U8FT].

123. Bressman, supra note 112, at 504.

124. Watts, supra note 105 , at 8-9.

125. Id. at 9 .

126. See supra Part III.A (describing the courts' focus on agencies' compliance with their regulatory mandate while declining to credit political factors).

127. Shapiro \& Murphy, supra note 66, at 1474. 
the president, as much as an agency, is bound by the law-an agency's statutory mandate. And it still permits agencies to follow presidential preferences, but they must establish that they are acting consistent with an agency's mandate to protect the public or the environment.

Sunstein and Vermeule have also proposed that the courts consider presidential preferences. But their proposal would allow the courts to take into consideration presidential preferences unrelated to an agency's statutory mandate in certain circumstances. ${ }^{128}$ Under their proposed "anti-circumvention principle," an agency could not reject a rulemaking petition if it would circumvent express or implied congressional instructions by deferring agency action. ${ }^{129}$ This limitation is necessary, they contend, to prevent "decisions not to decide, or to defer decisions" from becoming "a license for agencies to circumvent policy choices that Congress was entitled to make and did make, solely on the invalid ground that the agency disagrees with those policy choices." ${ }^{130}$ If, however, Congress has issued no such instructions, Sunstein and Vermeule would continue the uber-deference that the courts use in reviewing an agency's justifications for rulemaking inaction, ${ }^{131}$ and they would accept reasons that do not relate to the agency's statutory mandate, which would include presidential preferences. ${ }^{132}$

My objection to these proposals is that they constitute a fundamental break from the role of administrative law in constraining politics. Specifically, it permits the courts to defer to presidential preferences unrelated to an agency's mandate as long as such preferences do not circumvent express or implied congressional instructions. Watts, Sunstein, and Vermeule want the courts to legitimate agency activity in part if it has a presidential endorsement. Sunstein and Vermeule are prepared to accept such reasons because "the President is highly accountable." 133 For the reasons identified earlier, ${ }^{134}$ one can dispute the claim that the President is "highly accountable."

128. Sunstein \& Vermeule, supra note 6, at 161-62.

129. Id. at 162 .

130. Id. at $182-83$.

131. Id. at 162 .

132. Id. at 161 .

133. See supra note 123 and accompanying text.

134. See supra notes 109-122 and accompanying text. 
Watts is less trusting and would ban citing administration preferences if they constitute raw or partisan politics. But it is not clear how a court would make that determination in the context of rulemaking inaction where there is a limited record and litigants who challenge inaction are handicapped by that limitation.

More fundamentally, the trio has untethered administrative law from the principle that the president must act consistently with an agency's mandate unless Congress establishes that obligation in an express or implied manner. This leaves presidential compliance with agency mandates to the judgment of judges, centering upon whether Congress has "explicitly or impliedly" limited the president's freedom of action and weakens the protection of administrative law as a guarantor of the rule of law.

Sunstein and Vermeule might respond that, if Congress has not at least impliedly limited agency compliance with presidential preferences that do not relate to an agency's statutory mandate, the rule of law is not challenged. Congress has left it up to the agency and the president when to engage in rulemaking inaction. But this response ignores the overall thrust of the legislation to protect regulatory beneficiaries. When Congress passes a law protecting people or the environment, it is not accurate to read that law as saying you can dump this protection in favor of some other presidential priority - say foreign policy - if you would like to do so. The law itself is an explicit rejection of that premise.

Different people will reach different conclusions concerning the appropriate balance between politics and policy in rulemaking based on their experiences and expectations. My goal is to protect the interests of statutory beneficiaries in the context of rulemaking inaction. Along with Judge Skelly Wright, I am concerned that "important legislative purposes, heralded in the halls of Congress, are not lost or misdirected in the vast hallways of the federal bureaucracy." ${ }^{35}$ Administrative law does this best when it requires agencies to defend their choices as consistent with their statutory mission without regard to presidential preferences that are, for the most part, unaccountable to the electorate or unaccountable in time to protect the interests of regulatory beneficiaries.

135. Calvert Cliffs' Coordinating Comm. Inc. v. U.S. Atomic Energy Comm'n, 449 F.2d 1109, 1111 (D.C. Cir. 1971). 


\section{Less Passive Judicial Review}

If administrative law is to be legal civics, judges will have to employ a less deferential form of review than the toothless scope of review now used for rulemaking inaction. Instead of "extremely limited" and "highly deferential" review, ${ }^{136}$ the courts should expect agencies to offer an adequate explanation for the rejection of a petition or a delay in responding to a petition. The scope of review, in other words, should be just the same as when an agency adopts a rule, prompting a judge to take a hard look at the agency's explanation. ${ }^{137}$ What constitutes an adequate explanation, however, would be adjusted in light of the lack of a rulemaking record and the necessity of agency priority setting.

How a judge employs hard look review would necessarily have to change. When a judge reviews a rulemaking record, he or she he can compare the agency's justification for its actions with the record it has compiled. As there is no similar record in inaction cases, hard look review needs to be adapted. Although a judge cannot dive into a record, she or he can expect an agency to offer more than a perfunctory defense of its inaction and to back up its claims about priorities with an explanation that is "adequate" to back up these claims.

If, for example, the agency claims a lack of resources, judges should expect budget details about the agency's inability to work on more rulemaking projects. If the agency claims that it has higher priorities, the judge should expect the agency to explain why the other rules being drafted are more likely to fulfill its statutory mandate.

At the same time, judges should be reluctant to accept an explanation for inaction that posits an agency is too busy deregulating to take up regulatory proposals. An important aspect of this mood change is the recognition that agencies have an obligation to engage in regulation as defined by their statutory mandate. Judges should therefore be skeptical if an agency defends rulemaking inaction on the grounds it is too busy deregulating to work on new protections. That reason should be unacceptable because it is not one that is within the ambit of the agency's legislative mandate.

136. Massachusetts v. EPA, 549 U.S. 497, 527-28 (2007) (quoting Nat'l Customs Brokers \& Forwarders Ass'n. of Am. v. United States, 883 F.2d 93, 96 (D.C. Cir. 1989)).

137. DANiEl A. FARber, Lisa HeInZERling \& PETER M. SHANe, Reforming "REgUlATORY REFORM": A PROGRESSIVE FRAMEWORK FOR AGENCY RULEMAKING IN THE PUBLIC INTEREST 13 (Oct. 2018), https://www.acslaw.org/wp-content/uploads/2018/10/Oct-2018APA-Farber-Heinzerling-Shane-issue-brief.pdf [https://perma.cc/4FPW-HB7U]. 
That said, this does not mean that an agency should not be able to engage in a mix of activities including rule revocation, modification, and inaction as well as protective regulations. But the agency does need to offer a justification that its particular overall approach is consistent with its statutory mandate.

This new mood also does not preclude an agency from choosing to work on some rules rather than others based on legal and political factors. Once again, however, the agency is obligated to defend its mix as furthering its statutory mission to protect the public or the environment. Avoiding problematic rules and working instead on more feasible rules serves that mission.

I have a hesitation, however, about Sharon Jacobs's proposal allowing agencies to accept, as a justification for rulemaking inaction, that the judicial or political environment is unfavorable. ${ }^{138}$ As said, when an agency lives to fight another day, it may better its chances to engage in the type of protections that Congress mandated in its statute. ${ }^{139}$ In a deregulatory administration, however, such a "practical consideration" may permit an agency to go years without any forward motion toward protecting regulatory beneficiaries. ${ }^{140} \mathrm{It}$ is one thing to choose protective rules that have a better chance of being implemented for legal and political reasons, but it is another to stop work on protective rules because the president is not committed to protecting regulatory beneficiaries. At bottom, this justification violates the agency's statutory mandate to protect the public.

The aim is to change the "mood" of judicial review. ${ }^{141}$ Use of hard look review, instead of soft look review, recognizes the judiciary's responsibility to ensure that an agency action and inaction are both within the agency's statutory delegation; both types of "action" require the same level of judicial scrutiny. The redefinition of the scope of review would signal that regulatory beneficiaries are no longer secondclass citizens when it comes to ensuring the rule of law, but instead are entitled to the same scope of review as regulated entities. Whether a court is reviewing action or inaction, the question is the same: Is the

138. See Sharon B. Jacobs, The Administrative State's Passive Virtues, 66 ADMIN. L. REV. 565, 616 (2014) (asserting that agencies should be able to avoid political and legal entanglements).

139. Id. at 606 .

140. See id. (proposing that courts recognize political and legal impediments as practical constraints).

141. See supra note 15 and accompanying text. 
agency operating within the legal space as specified by its legislative mandate?

Skeptics will object that judges are likely to do more harm than good once they engage in more searching review of the reasons that agencies offer for rulemaking inaction. The idea is that courts will be able to avoid blundering in light of the complexity involved in priority setting and the multiple factors that an agency considers. The courts, however, can employ judicial remands to require a more adequate justification if an agency falls short, which protects judges from rushing in to readjust an agency's priorities. ${ }^{142}$ My proposal does expect agencies to be able to explain their inaction decisions with persuasive details, but it allows judges to accept those explanations once they are forthcoming.

It is also possible that a change in the definition of the scope of review would make no difference. Once agencies furnished some additional information, judges would then continue to defer to agency explanations for the same reasons they now employ uber-deferencenot wanting to interfere with agency priority setting and the lack of a record that could be used to check the validity of the agency's reasons.

Judges, however, may not be so inclined once agencies have a judicially enforced obligation to offer an "adequate" explanation for inaction, one that consists of more than a rudimentary recitation of a lack of resources and higher priorities. The requirement of adequate reasons will remind judges that Congress has established both a floor and a ceiling when it passes regulatory legislation, and the failure to be more inquisitive regarding inaction constitutes a judicial failure to enforce the floor. At the moment, by comparison, the idea of a legislative floor is invisible to judges. The assumption appears to be that Congress has delegated priority setting to agencies, and courts honor this request by using uber-deference. In short, once the framework of review is changed, the results are more likely to change as well.

Moreover, once judges ask agencies for more specific information as to why they are rejecting a rulemaking petition, there is more opportunity for petitioners to challenge the decision than under the current judicial genuflection to agency justifications that waive the flag of resources and not much more.

142. Garland, supra note 79, at 565. 
There are two additional advantages to my proposal. First, more skeptical judicial review can incentivize agencies to create a priority setting process or improve an existing process, something that agencies always do or keep up to date. ${ }^{143}$ It can also force agencies to offer concrete information to back up assertions about agency priorities more quickly and efficiently. More generally, a priority setting process is a key element of effective implementation of an agency's statutory mandate when it identifies the best ways to achieve an agency's statutory mandate to protect people and the environment. In short, it is good governance.

Second, the public will gain more information about agency priorities and resources when judges expect agencies to offer more detailed explanations for a lack of action. In this sense, an "explained" delay is better than an "unexplained" delay. ${ }^{144}$ In particular, agency explanations based on a lack of resources may signal to Congress that agencies lack sufficient funding to implement more worthwhile rules to protect people and the environment. As I have discussed elsewhere, there is a lack of information regarding what additional protections an agency could adopt if it had additional resources. ${ }^{145}$

It is also possible that soft look review will divert an agency from working on current projects because of the obligation to offer a more adequate explanation or to respond to a judicial remand to do so. ${ }^{146} \mathrm{As}$ stated, an agency can reduce the resources it expends on defending inaction in court by establishing and using a priority setting process. But, even if there is some loss of agency efficiency, it is a price worth paying because of the advantages of soft review identified in the previous paragraphs.

Despite these improvements, there is a practical limit to the extent to which judges will be able to ferret out the strategic use of inaction as a deregulatory tool. Although judicial review will be less deferential, it will still be deferential. And it should be. Judges will still be handicapped by the lack of a record against which they can test the claims made by the agency regarding inaction. To adopt a cliché,

143. See MCGARITY \& SHAPIRO, supra note 2, at 187-88 (noting that OSHA, for example, "has no way to choose among the many projects that are putatively on its agenda").

144. Shapiro \& Murphy, supra note 66, at 1496.

145. See STEINZOR \& SHAPIRO, supra note 65, at 69, 227 (explaining that Congress lacks information about how much money agencies need to implement their statutory mission).

146. See Jacobs, supra note 138, at 613 (objecting to expanding reason-giving for inaction on the grounds that it would take more agency resources and therefore significantly exacerbate an agency's lack of resources). 
however, we should not let perfect be the enemy of the good. The courts can do a better job of policing inaction, and they should do so.

\section{CONCLUSION}

The Trump administration may be the first presidency to go four years without promulgating new significant regulations to protect people and the environment. But the use of rulemaking inaction as a deregulatory strategy has been employed in previous administrations hostile to government regulation. Although administrative law protects regulatory beneficiaries when agencies revoke or modify previous rules, those protections evaporate when an agency rejects a rulemaking petition, fails to answer a petition for years, or fails to work on pending regulatory protections.

This state of affairs arises because the courts have been reluctant to second-guess agency inaction based on agency priority setting, and reasonably so because of the difficulty of judging whether an agency has struck the proper balance among the multiple factors that go into priority setting. In effect, the courts have outsourced agency accountability for rulemaking inaction to political oversight.

As a defense of the interests of regulatory beneficiaries, political accountability is the "Maginot Line" of oversight. And even if voters would somehow replace a president who ignores their interests, that president will still have delayed protections for up to eight or more years, given how long it would take an administration interested in protection to promulgate new significant rules.

Despite the difficulty of judging an agency's claim that it has higher priorities or that it needs more time to make a decision, the courts can still do better. Administrative law constrains politics by requiring agencies to justify their actions as consistent with their legislative mandates. Instead of merely accepting agency claims about priorities, the courts should demand more detailed explanations. If explanations fall short, remands to allow the agency another chance to explain would be in order. Although not a cure for administration obstructionism, judicial review would no longer be a parchment barrier.

Raising judicial expectations about what constitutes an adequate explanation for rulemaking inaction, even if it has only modest impact, aligns this area of the law with the role of administrative law in setting a floor and ceiling on agency policymaking. Just as an agency cannot exceed its statutory authority, it should not be able to avoid it either by 
inaction. If administrative law is to legitimize agency action, the courts must enforce, as best they can, an agency's obligation to protect people or the environment. 